MILAN STANKOVIĆ, M.Sc.

E-mail: milan.stankovic@hac.hr

ZVONIMIR PILIH, M.Sc.

E-mail: zvonimir.pilih@hac.hr

Croatian Motorways Ltd.

Širolina 4, HR-10000 Zagreb, Republic of Croatia

BOŽIDAR IVANKOVIĆ, M.Sc.

E-mail: ivankovb@fpz.hr

University of Zagreb,

Faculty of Transport and Traffic Sciences

Vukelićeva 4, HR-10000 Zagreb, Republic of Croatia
Traffic on Motorways

Review

Accepted: Sep. 17, 2008

Approved: Sep. 16, 2009

\title{
CALCULATION OF TIME LOSSES DUE TO TOLL COLLECTION
}

\begin{abstract}
Fast development of tertiary activities has deleted the borderline between the working and free time, workdays and holidays. The highways reduce the time of individual transport by personal and cargo vehicles due to higher travelling speeds, but toll collection results in time losses due to obligatory stopping of vehicles. The objective of the study presented in the paper is the exact calculation of the time losses caused by toll collection. The simulation method based on the technical characteristics of the vehicles has been combined with the analysis of the register of toll collection dynamics. Since the queuing losses at peak and off-peak periods have not been taken into consideration, the obtained values of losses are minimal. The paper considers various technologies of toll collection.
\end{abstract}

\section{KEYWORDS}

travelling speed, acceleration, toll collection, assessment

\section{INTRODUCTION}

Toll collection is a very old model of collecting means intended for the construction and maintenance of roads, dating back to the times of the Roman Empire.

In the recent years, the classical toll collection method performed by attendants at toll booths is being transferred to the electronic toll collection system (ENC), which requires the introduction of additional traffic lanes for the free flow of vehicles at toll passages.

The technological development leads to a search for new solutions, and there is a developed concept of "virtual toll collection", i.e. third-generation toll collection. In this system the GPS detects the position of a vehicle, the OBU device (On-board Unit) via GSM charges toll without any time loss and without disturb- ing the motorist, so that the toll collection capacity has been balanced with the highway capacity.

This paper calculates the time losses due to the second generation toll collection (ENC) implemented in Croatia, and the losses in manual toll collection. The saving brought by the third generation toll collection system has been simulated.

The paper has been divided into four sections followed by a conclusion and recommendations for further research. The next section emphasises the advantages and drawbacks of the known toll collection systems. The third section contains an exact calculation of the minimal time losses in the current toll collection systems of the Republic of Croatia which assume complete stopping of vehicles. Heavy vehicles are considered with special attention because their time losses depend on the engine power and on the load. The passenger vehicles are more manoeuvrable and the load weight has little impact on their acceleration which is set by the manufacturer's time performance of reaching $0-100 \mathrm{~km} / \mathrm{h}$. The next section contains simulations of losses for the values of single vehicles and the stopping conditions. The actual data on time losses in case of manual toll collection are presented in the fifth section, together with the simulations for the cargo and passenger vehicles. The section preceding the conclusion calculates the loss evaluation in the Croatian kuna based on the actual data on traffic and transport in 2007.

\section{ADVANCED TOLL COLLECTION}

The ENC system is used practically everywhere and due to its advantages it has entered the standard use. The communication system DSRC (dedicated short-range communications) allows information ex- 
change between the ENC devices onboard vehicle and the device along the road. The system can be improved so as to eliminate complete stopping of vehicles with a more complex infrastructure, but there is still a certain deceleration of traffic. The infrastructure is presented in Figure 1.

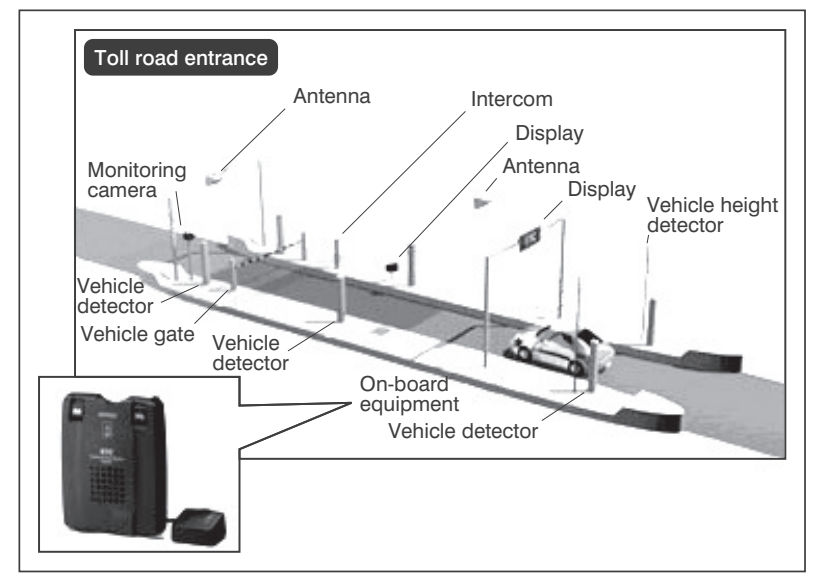

Figure 1 - Electronic toll collection by DSRC technology: ENC

Source: http://www.globaldensoproducts.com/ic/electronic_toll.html

In the third-generation toll collection system [3], the exact position of the vehicle is detected by the GPS, but the vehicle must have an installed OBU with a database. The onboard database provides the exact location of the toll collection points, and the system of mobile telephony (GSM) reports on the vehicle passage through the toll collection point. The implementation of such a system avoids the cost of building the toll booths [4], since the toll collection occurs without road passages and without the stopping requirement.

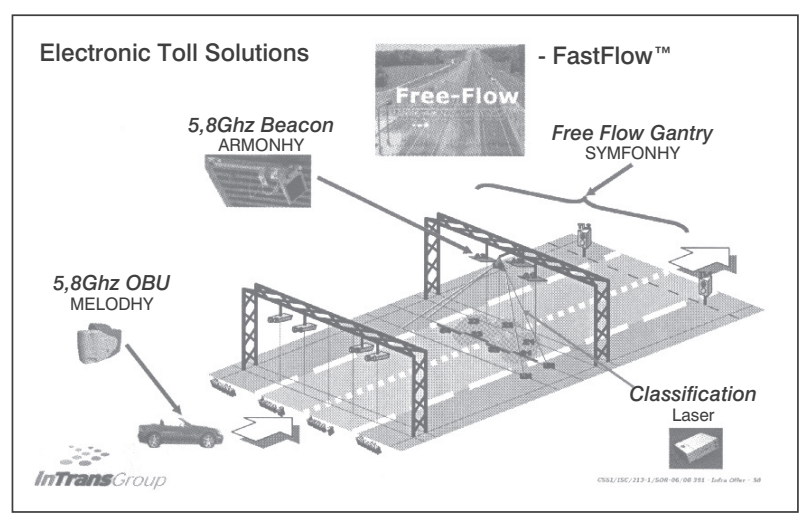

Figure 2 - Fast toll collection system using GPS technology

Source: http://www.globaldensoproducts.com/ic/electronic_toll.html CS Communication \& Systems, France (www.c-s.fr)

Investment into the third-generation system based on GPS is more than five times higher than the investment into the DSRC system (in [5] the ratio is 90:16). It is precisely the time losses caused by stopping for toll collection obtained in this paper that suggest the non-stopping toll collection version. The example of the Czech Republic [3] where a third-generation system was implemented within nine months on its $1160 \mathrm{~km}$ of highways and where the revenues in 2007 amounted to EUR 200,000,000 provides a serious argument in the decision on introducing a similar system in the Republic of Croatia.

The systems react differently to avoiding of toll collection. In DSRC one can immediately read whether the ENC device is onboard vehicle and whether it operates. In case the contact has not been realized, the user certainly receives the information on failure to pay the toll. In GPS the situation is rather different. The manoeuvre of GPS coverage or cellular antenna coverage in order to avoid toll collection passes unobserved all the way to the contact with a control point. The efficiency of the control part of this system, thus, still remains to be proven in practice, so that the toll collection agencies need to make decisions for themselves during the running-in period of the system.

Privacy is a special issue since the GPS is an efficient tracking system. At any moment one may know the position of the user and save the information for further usage, thus intruding on the privacy to the extent that does not have to be tolerated.

Both systems have their advantages and drawbacks, considered over a long run, the vehicles will probably use both GPS and DSRC systems.

Prepaid toll as imposed road toll regardless of the used highway kilometres is not fair, nor has the cost of controlling toll avoidance been studied. Toll collection that takes into consideration the travelled kilometres of the highway is fairer for the user. The time and environmental losses, as well as reduced safety because of traffic disturbance can be successfully solved by the third-generation toll system which today exists already in the developed countries.

\section{TIME LOSS DUE TO VEHICLE STOPPING}

Time losses in the ENC system result due to the reading of the stopped vehicle, so that the vehicle needs to slow down, stop and start again (details in [1]). For passenger vehicles the values have been predefined as parameters. The travelling speed $v_{0}$ is usually measured in $\mathrm{km} / \mathrm{h}$. The stopping distance $s_{0}$ is defined by the infrastructure and the speed limits and is expressed in metres $m$. Maximum acceleration is expressed in case of passenger vehicles in time $t_{0}(s)$ necessary for the vehicle to accelerate from the stationary position to the speed of $100 \mathrm{~km} / \mathrm{h}$. 
The stopping time $t_{z}$ in seconds, for predefined values measured in the mentioned measurement units, equals

$$
t_{z}=\frac{7.2 \cdot s_{0}}{v_{0}}
$$

Time $t_{u}$ necessary for the passenger vehicle to accelerate from the stationary position to the travelling speed $v_{0}$ is obtained according to formula

$$
t_{u}=\frac{v_{0} t_{0}}{100} \text {. }
$$

If the reading time is neglected, the bottom limit of time $T_{N}$ is obtained, which is necessary to read the ENC charging which consists of the stopping time $t_{z}$ and the acceleration time $t_{u}$ :

$T_{N} \geq \frac{720 s_{0}+v_{0}^{2} t_{0}}{100 v_{0}}$

Path $s_{u}$ that a vehicle has to travel in order to reach the travelling speed $v_{0}$ equals

$$
s_{u}=\frac{v_{0}^{2} \cdot t_{0}}{720} .
$$

Time $T_{0}$ in which a vehicle could pass the point of toll collection without stopping is half the time necessary for stopping and amounts in seconds:

$T_{0}=\frac{720 \cdot s_{0}+v_{0}^{2} \cdot t_{0}}{200 \cdot v_{0}}$.

The total time loss $\Delta T$ due to ENC charging per passenger vehicle at the entry and exit, is now greater than the difference

$\Delta T=2 \cdot\left(T_{N}-T_{0}\right)=2 \cdot\left(2 T_{0}-T_{0}\right)=2 \cdot T_{0}=T_{N}:$

$\Delta T=T_{N} \geq \frac{720 \cdot s_{0}+v_{0}^{2} \cdot t_{0}}{100 \cdot v_{0}}$.

Acceleration of heavy motor vehicles depends on the vehicle mass $m$ which is expressed in tonnes $t$ and engine power $P$ which is expressed in kilowatts $k W$ (measurement unit outside the SI system is the common horse power: $1 \mathrm{HP}=0.73549 \mathrm{~kW}$ ). The travelling speed $v_{0}$ is measured in $\mathrm{km} / \mathrm{h}$. Maximum acceleration of the heavy vehicle in $m / \mathrm{s}^{2}$ equals

$a=\frac{7.2 \cdot P-\mu \cdot m \cdot g \cdot v_{0}}{m \cdot v_{0}}$,

where $\mu$ is the measured friction coefficient, and $g$ gravitational acceleration which at the latitude of the Republic of Croatia amounts to $9.81 \mathrm{~m} / \mathrm{s}^{2}$.

The minimum time necessary for the heavy vehicle to accelerate and reach the travelling speed amounts to

$t_{u}=\frac{m \cdot v_{0}^{2}}{25.92 \cdot P-3.6 \cdot \mu \cdot m \cdot g \cdot v_{0}}$.

The distance travelled during acceleration equals: $s_{u}=\frac{m \cdot v_{0}^{3}}{186.624 \cdot P-25.92 \cdot \mu \cdot m \cdot g \cdot v_{0}}$.

If the stopping distance for heavy vehicles is determined by the traffic signs and amounts to $s_{0}$, then due to stopping the heavy vehicle loses time $T_{N}$ which in seconds amounts to at least:

$T_{N} \geq \frac{m \cdot v_{0}^{2}}{25.92 \cdot P-3.6 \cdot \mu \cdot m \cdot g \cdot v_{0}}+\frac{7.2 \cdot s_{0}}{v_{0}}$.

At travelling speed the vehicle would pass the entire path without stopping in the duration of $T_{0}$, which in seconds $(s)$ amounts to

$T_{0}=\frac{m \cdot v_{0}^{2}}{186.624 \cdot P-25.92 \cdot \mu \cdot m \cdot g \cdot v_{0}}+\frac{3.6 \cdot s_{0}}{v_{0}}$.

Total time loss $\Delta T$ for ENC system charging at the entry and exit, in seconds, amounts to

$\Delta T \geq \frac{12.4 \cdot m \cdot v_{0}^{2}}{186.624 \cdot P-25.92 \cdot \mu \cdot m \cdot g \cdot v_{0}}+\frac{7.2 \cdot s_{0}}{v_{0}}$.

Air resistance is neglected because it is maximum at the travelling speed, and the difference is observed between the time spent on reading by ENC technology with stopping and the reading technologies without vehicle stopping, at their travelling speed.

\section{SIMULATION OF TIME LOSSES DUE TO VEHICLE STOPPING}

In Tables 1 and 2 the concrete values are calculated according to formulas constructed in Section 3, resulting in values of the minimum time losses due to vehicle stopping and reacceleration to the travelling speed. The least total time loss is calculated using formula (3).

In calculating the time necessary for ENC toll collection in Tables 1 and 2 the reading time per vehicle has been neglected. The third row in the Table has been highlighted for its representativeness. The automobile at travelling speed $v_{0}=120 \mathrm{~km} / \mathrm{h}$ before entering the ENC portal decelerates over a distance of $100 \mathrm{~m}$, stops and reaccelerates to the travelling speed.

The minimum time necessary for toll collection $T_{N}$ was calculated according to formula (3), and the passage time without stopping $T_{0}$ was obtained according to formula (2). $T_{N}$ and $T_{0}$ yield the total time loss in the ideal case. The vehicle, namely, passes twice the ENC lane.

Values $\mathrm{T}(\mathrm{N}), \mathrm{T}(0)$ and $\Delta \mathrm{T}$ represent values $T_{N}, T_{0}$ and $\Delta T$ defined by formulas (7), (8) and (9), respectively. The travelled path $\mathrm{L}$ in lost time has been obtained by multiplying the travelling speed by the minimum total time loss. 
Table 1 - Simulation of time losses due to passenger vehicle stopping

\begin{tabular}{|c|c|c|c|c|c|c||}
\hline Ord. No. & $\begin{array}{c}\text { Travel } \\
\text { speed }\end{array}$ & $\begin{array}{c}\text { Stopping dis- } \\
\text { tance before } \\
\text { entry }\end{array}$ & $\begin{array}{c}\text { Time } \\
0-100 \\
\mathrm{~km} / \mathrm{h}\end{array}$ & $\begin{array}{c}\text { Minimum time } \\
\text { needed for toll } \\
\text { collection }\end{array}$ & $\begin{array}{c}\text { Time of passage } \\
\text { without stopping }\end{array}$ & $\begin{array}{c}\text { Minimal total time } \\
\text { loss }\end{array}$ \\
\hline \hline meas. unit & $\mathrm{km} / \mathrm{h}$ & $\mathrm{m}$ & $\mathrm{s}$ & $\mathrm{s}$ & $\mathrm{s}$ & $\mathrm{s}$ \\
\hline \hline 1. & 130 & 100 & 15 & 25.0 & 12.5 & 25.0 \\
\hline 2. & 120 & 100 & 12.5 & 21.0 & 12.6 & 21.0 \\
\hline 3. & 100 & 100 & 18 & 25.2 & 9.6 & 25.2 \\
\hline 4. & 130 & 100 & 10.5 & 19.2 & 8.9 & 19.2 \\
\hline 5. & 130 & 100 & 9.5 & 17.9 & 9.9 & 17.9 \\
\hline 6. & 100 & 100 & 12.5 & 19.7 & 9.1 & 19.7 \\
\hline 7. & 100 & 80 & 12.5 & 18.3 & 8.1 & 18.3 \\
\hline 8. & 100 & 50 & 12.5 & 16.1 & 16.1 \\
\hline
\end{tabular}

Table 2 - Simulation of time losses due to the stopping of heavy vehicles

\begin{tabular}{|c|c|c|c|c|c|c|c|c|c|}
\hline Ord. No. & $\begin{array}{l}\text { Travel } \\
\text { speed }\end{array}$ & $\begin{array}{c}\text { Stopping } \\
\text { distance } \\
\text { before entry }\end{array}$ & $\begin{array}{l}\text { Veh. } \\
\text { power }\end{array}$ & $\begin{array}{l}\text { Veh. } \\
\text { mass }\end{array}$ & Friction & $\begin{array}{l}\text { Min. time } \\
\text { for toll } \\
\text { collection }\end{array}$ & $\begin{array}{l}\text { Time of pas- } \\
\text { sage without } \\
\text { stopping } \\
\end{array}$ & $\begin{array}{l}\text { Min. total } \\
\text { time loss }\end{array}$ & $\begin{array}{c}\text { Travelled } \\
\text { path in lost } \\
\text { time }\end{array}$ \\
\hline Value & $\mathrm{v}(0)$ & $\mathrm{s}(0)$ & $\mathrm{P}$ & $\mathrm{m}$ & \multirow{2}{*}{$\mu$} & $\mathrm{T}(\mathrm{N})$ & $\mathrm{T}(0)$ & $\Delta \mathrm{T}$ & $\mathrm{L}$ \\
\hline meas. unit & $\mathrm{km} / \mathrm{h}$ & $\mathrm{m}$ & $\mathrm{kW}$ & $\mathrm{t}$ & & $\mathrm{s}$ & $\mathrm{s}$ & $\mathrm{s}$ & $\mathrm{m}$ \\
\hline 1 & 80 & 100 & 400 & 30 & 0.0120 & 29.5 & 4.5 & 50.1 & 1112 \\
\hline 2 & 90 & 100 & 400 & 40 & 0.0120 & 31.3 & 4.0 & 54.5 & 1362 \\
\hline 3 & 80 & 100 & 250 & 30 & 0.0120 & 29.6 & 4.5 & 50.3 & 1117 \\
\hline 4 & 80 & 100 & 380 & 45 & 0.0120 & 29.2 & 4.5 & 49.5 & 1099 \\
\hline 5 & 80 & 100 & 250 & 25 & 0.0120 & 24.7 & 4.5 & 40.4 & 897 \\
\hline 6 & 80 & 80 & 350 & 30 & 0.0120 & 21.2 & 3.6 & 35.1 & 780 \\
\hline 7 & 80 & 50 & 350 & 25 & 0.0120 & 17.6 & 2.3 & 30.8 & 684 \\
\hline 8 & 80 & 100 & 250 & 20 & 0.0120 & 19.8 & 4.5 & 30.5 & 678 \\
\hline
\end{tabular}

\section{TIME LOSS DUE TO MANUAL TOLL COLLECTION}

The loss in case of manual toll collection increases the amounts obtained in Tables 1 and 2 for time $t_{k}$ required by the user to collect the ticket at the entry and time $t_{n}$ required by the user to pay for using the highway. lows

Time necessary to collect the ticket ranges as fol-

$$
15 \mathrm{~s} \leq t_{k} \leq 20 \mathrm{~s}
$$

determined by measuring the real time at the Ivanja Reka entry at peak load on 1 August 2009. The tables analogue to Tables 3 have been left out for the sake of economy, and are available to the authors.

Time lost due to manual toll collection was determined by dividing the working hours of a toll booth attendant in one shift ( 8 hours) by the number of charged vehicles in individual full intensity traffic in the days of higher loads presented in Tables 3 .

Time in seconds per vehicle depends on the inflow of vehicles which does not have to be continuous during the working hours at every toll booth attendant's place. The time of manual toll collection for one user can be measured only at moments of peak load. Thus, Table 3 yields the minimum time loss in the following range:

$$
20 \mathrm{~s} \leq t_{n} \leq 30 \mathrm{~s}
$$

Total time lost due to manual toll collection encompasses the time of collecting the ticket at the entry and the time of charging at the exit, and ranges as follows

$$
35 \mathrm{~s} \leq t_{k}+t_{n} \leq 50 \mathrm{~s}
$$

Time lost for stopping and acceleration is equal to the case of ENC charging and calculated in the third section of the paper. The total time $\Delta T_{r}$ lost in case of manual toll collection can be limited now to: 
Tables 3 -Overview of charged vehicles per toll booth attendant at Ivanja Reka toll gates

\begin{tabular}{|c|c|c|c|c|c|c|c|c|c|c|c|c|c|c|c|}
\hline \multicolumn{10}{|c|}{ 24.08.2008 06:00:00 - 24.08.2008 13:59:59 } & \multicolumn{2}{|c|}{ ENC lane } & \multicolumn{4}{|c|}{$\begin{array}{l}\text { Average of manually charged vehicles per } \\
\text { toll booth attendant without ENC lanes }\end{array}$} \\
\hline $\begin{array}{c}\text { Em- } \\
\text { ployee }\end{array}$ & $\begin{array}{l}\text { Exit } \\
003 \\
\end{array}$ & $\begin{array}{c}\text { Exit } \\
004\end{array}$ & $\begin{array}{l}\text { Exit } \\
005\end{array}$ & $\begin{array}{l}\text { Exit } \\
006 \\
\end{array}$ & $\begin{array}{c}\text { Exit } \\
007\end{array}$ & $\begin{array}{l}\text { Exit } \\
008\end{array}$ & $\begin{array}{l}\text { Exit } \\
009 \\
\end{array}$ & $\begin{array}{c}\text { Exit } \\
010 \\
\end{array}$ & $\begin{array}{l}\text { Exit } \\
011 \\
\end{array}$ & $\begin{array}{l}\text { Exit } \\
012 \\
\end{array}$ & $\begin{array}{l}\text { Exit } \\
013 \\
\end{array}$ & $\begin{array}{l}\text { number of } \\
\text { veh./ hour }\end{array}$ & $\begin{array}{l}\text { number of } \\
\text { veh. / min. }\end{array}$ & $\begin{array}{l}\text { sec. per } \\
\text { veh. }\end{array}$ & $\begin{array}{c}\text { Average } \\
(\mathrm{sec})\end{array}$ \\
\hline 130985 & & & 1002 & & & & & & & & & 125.3 & 2.1 & 28.7 & \multirow{7}{*}{27.4} \\
\hline 144168 & & & & 1183 & & & & & & & & 147.9 & 2.5 & 24.3 & \\
\hline 131058 & & & & & 1218 & & & & & & & 152.3 & 2.5 & 23.6 & \\
\hline 131082 & & & & & & 1065 & & & & & & 133.1 & 2.2 & 27.0 & \\
\hline 131108 & & & & & & & 1028 & & & & & 128.5 & 2.1 & 28.0 & \\
\hline 130936 & & & & & & & & 892 & & & & 111.5 & 1.9 & 32.3 & \\
\hline 130886 & & & & & & & & & 1050 & & & 131.3 & 2.2 & 27.4 & \\
\hline 430688 & & & & & & & & & & & 132 & 16.5 & 0.3 & 218.2 & 218.2 \\
\hline
\end{tabular}

\begin{tabular}{|c|c|c|c|c|c|c|c|c|c|c|c|c|c|c|c|}
\hline \multicolumn{10}{|c|}{ 24.08.2008 06:00:00 - 24.08.2008 13:59:59 } & \multicolumn{2}{|c|}{ ENC lane } & \multicolumn{4}{|c|}{$\begin{array}{l}\text { Average of manually charged vehicles per } \\
\text { toll booth attendant without ENC lanes }\end{array}$} \\
\hline $\begin{array}{l}\text { Em- } \\
\text { ployee }\end{array}$ & $\begin{array}{l}\text { Exit } \\
003\end{array}$ & $\begin{array}{l}\text { Exit } \\
004\end{array}$ & $\begin{array}{c}\text { Exit } \\
005\end{array}$ & $\begin{array}{c}\text { Exit } \\
006\end{array}$ & $\begin{array}{c}\text { Exit } \\
007\end{array}$ & $\begin{array}{c}\text { Exit } \\
008\end{array}$ & $\begin{array}{c}\text { Exit } \\
009\end{array}$ & \begin{tabular}{c|} 
Exit \\
010
\end{tabular} & $\begin{array}{c}\text { Exit } \\
011\end{array}$ & $\begin{array}{c}\text { Exit } \\
012\end{array}$ & \begin{tabular}{c|} 
Exit \\
013
\end{tabular} & $\begin{array}{l}\text { number of } \\
\text { veh. / hour }\end{array}$ & $\begin{array}{l}\text { number of } \\
\text { veh. / min. }\end{array}$ & $\begin{array}{l}\text { sec. per } \\
\text { veh. }\end{array}$ & $\begin{array}{c}\text { Average } \\
(\mathrm{sec})\end{array}$ \\
\hline 131074 & 1082 & & & & & & & & & & & 135.3 & 2.3 & 26.6 & \multirow{11}{*}{28.4} \\
\hline 133310 & & 903 & & & & & & & & & & 112.9 & 1.9 & 31.9 & \\
\hline 144788 & & 1369 & & & & & & & & & & 171.1 & 2.9 & 21.0 & \\
\hline 130787 & & & 1273 & & & & & & & & & 159.1 & 2.7 & 22.6 & \\
\hline 134136 & & & & 1077 & & & & & & & & 134.6 & 2.2 & 26.7 & \\
\hline 130845 & & & & & 1304 & & & & & & & 163.0 & 2.7 & 22.1 & \\
\hline 130803 & & & & & & 1286 & & & & & & 160.8 & 2.7 & 22.4 & \\
\hline 131140 & & & & & & & 1222 & & & & & 152.8 & 2.5 & 23.6 & \\
\hline 131405 & & & & & & & & 1230 & & & & 153.8 & 2.6 & 23.4 & \\
\hline 144770 & & & & & & & & & 1039 & & & 129.9 & 2.2 & 27.7 & \\
\hline 144135 & & & & & & & & & & 449 & & 56.1 & 0.9 & 64.1 & \\
\hline 430670 & & & & & & & & & & 317 & & 39.6 & 0.7 & 90.9 & \multirow{2}{*}{70.9} \\
\hline 430670 & & & & & & & & & & & 565 & 70.6 & 1.2 & 51.0 & \\
\hline
\end{tabular}

Source: Hrvatske autoceste d. o. o (Croatian Highways Ltd.)

$$
35 \mathrm{~s}+\Delta T \leq \Delta T_{r} \leq 50 \mathrm{~s}+\Delta T
$$

where the values $\Delta T$ calculated by relations (3) for passenger and (9) heavy vehicles.

Inadequate values of sec. per veh. result due to big time intervals between subsequent vehicle arrivals and are marginal.

Tables 4 and 5 show the simulation of total time loss due to manual toll collection for passenger and for heavy motor vehicles.

The minimum and maximum time lost in case of manual toll collection has been calculated from the non-equation (10) in which $\Delta T$ has been calculated from expression (3) for passenger vehicles with the simulation from Table 1 , whereas $\Delta T$ for heavy vehicle is calculated from (9), for which the simulation is car- ried out in Table 2. In this way the time losses in manual toll collection in the current system have been obtained.

\section{EVALUATION OF TIME LOSSES}

During 2007 the ENC toll collection was performed only for passenger vehicles. The number of vehicles was around 22,000 and they realized 2,041,491 passages, which out of the total number of passages $49,887,787$, accounts for $4.09 \%$.

Total time loss in case of the so-called "stop-and-go" toll collection by means of ENC equals the prod- 
Table 4 - Simulation of time losses due to manual road toll collection of passenger vehicles

\begin{tabular}{|c|c|c|c|c|c|c|}
\hline Ord. No. & $\begin{array}{l}\text { Travel } \\
\text { speed }\end{array}$ & $\begin{array}{l}\text { Stopping distance } \\
\text { before entry }\end{array}$ & $\begin{array}{c}\text { Time } \\
0-100 \mathrm{~km} / \mathrm{h} \\
\end{array}$ & $\begin{array}{l}\text { Time of passage } \\
\text { without stopping }\end{array}$ & $\begin{array}{l}\text { Min. time of man- } \\
\text { ual toll collection }\end{array}$ & $\begin{array}{l}\text { Max. time of man- } \\
\text { ual toll collection }\end{array}$ \\
\hline value & $\mathrm{v}(0)$ & $\mathrm{s}(0)$ & $\mathrm{t}(0)$ & $\mathrm{T}(0)$ & $\Delta \operatorname{Tr}(\min )$ & $\Delta \operatorname{Tr}(\max )$ \\
\hline meas. unit & $\mathrm{km} / \mathrm{h}$ & $\mathrm{m}$ & $\mathrm{s}$ & $\mathrm{s}$ & $\mathrm{s}$ & $\mathrm{s}$ \\
\hline 1 & 130 & 100 & 15 & 12.5 & 60.0 & 75.0 \\
\hline 2 & 120 & 100 & 13 & 10.5 & 56.0 & 71.0 \\
\hline 3 & 100 & 100 & 18 & 12.6 & 60.2 & 75.2 \\
\hline 4 & 130 & 100 & 11 & 9.6 & 54.2 & 69.2 \\
\hline 5 & 130 & 100 & 9.5 & 8.9 & 52.9 & 67.9 \\
\hline 6 & 100 & 100 & 13 & 9.9 & 54.7 & 69.7 \\
\hline 7 & 100 & 80 & 13 & 9.1 & 53.3 & 68.3 \\
\hline 8 & 100 & 50 & 13 & 8.1 & 51.1 & 66.1 \\
\hline
\end{tabular}

Table 5 - Simulation of time losses in case of manual toll collection of heavy vehicles

\begin{tabular}{|c|c|c|c|c|c|c|c||}
\hline Ord. No. & $\begin{array}{c}\text { Travel } \\
\text { speed }\end{array}$ & $\begin{array}{c}\text { Stopping distance } \\
\text { before entry }\end{array}$ & $\begin{array}{c}\text { Veh. } \\
\text { power }\end{array}$ & $\begin{array}{c}\text { Veh. } \\
\text { mass }\end{array}$ & $\begin{array}{c}\text { Min. time of man- } \\
\text { ual toll collection }\end{array}$ & $\begin{array}{c}\text { Max. time of man- } \\
\text { ual toll collection }\end{array}$ & $\begin{array}{c}\text { Average travelled } \\
\text { path in lost time }\end{array}$ \\
\hline \hline value & $\mathrm{v}(0)$ & $\mathrm{s}(0)$ & $\mathrm{P}$ & $\mathrm{m}$ & $\Delta \operatorname{Tr}(\mathrm{min})$ & $\Delta \operatorname{Tr}(\mathrm{max})$ & $\mathrm{L}$ \\
\hline meas. unit & $\mathrm{km} / \mathrm{h}$ & $\mathrm{m}$ & $\mathrm{kW}$ & $\mathrm{t}$ & $\mathrm{s}$ & $\mathrm{s}$ & $\mathrm{m}$ \\
\hline \hline 1 & 80 & 100 & 400 & 30 & 80.1 & 100.1 & $\mathbf{1 0 4 . 5}$ \\
\hline $\mathbf{2}$ & $\mathbf{9 0}$ & $\mathbf{1 0 0}$ & $\mathbf{4 0 0}$ & $\mathbf{4 0}$ & $\mathbf{8 4 . 5}$ & 100.3 & $\mathbf{2 3 6 3}$ \\
\hline 3 & 80 & 100 & 250 & 30 & 80.3 & 99.5 & 2007 \\
\hline 4 & 80 & 100 & 380 & 45 & 79.5 & 90.4 & 1989 \\
\hline 5 & 80 & 100 & 250 & 25 & 70.4 & 85.1 & 1787 \\
\hline 6 & 80 & 80 & 350 & 30 & 65.1 & 80.8 & 1669 \\
\hline 7 & 80 & 50 & 350 & 25 & 60.8 & 80.5 & 1573 \\
\hline 8 & 80 & 100 & 250 & 20 & 60.5 & & 1567 \\
\hline
\end{tabular}

uct of the number of passages with time loss from Table 1 and on the average amounts to:

$$
2041491 \cdot 21 \mathrm{~s}=11900 \mathrm{~h}
$$

There were 47,846,296 passenger vehicles that were charged manually for toll in 2007 . The average time loss for collecting one charging card and for toll payment according to the results from Table 4 equals 63.5s.

The product of the number of vehicles and the collective time loss yields total time loss

$$
47846296 \cdot 63.5 \mathrm{~s}=843955 \mathrm{~h} .
$$

There were 6,991,873 heavy vehicles in 2007. The average sum of time losses in collecting the toll ticket at the entry and payment at the exit according to Table 5 is 94.5 seconds.

The product of the number of vehicles and the total time loss yields

$$
6991873 \cdot 94.5 \mathrm{~s}=183537 \mathrm{~h} .
$$

The value estimate took into consideration the time loss expressed in hours and the price of working hour calculated on the basis of the net average income in the Republic of Croatia which in 2007 amounted to $H R K 4,841$. By dividing the average income with the norm of 176 hours monthly, the price of one working hour of HRK 27.5 is obtained. The losses are now:

Manual toll collection:

$$
843955 \mathrm{~h} \cdot 27.5 \mathrm{HRK} / \mathrm{h}=23208762 \mathrm{HRK}
$$

ENC:

$$
11900 \mathrm{~h} \cdot 27.5 \mathrm{HRK} / \mathrm{h}=327250 \mathrm{HRK} \text {. }
$$

The value of loss for heavy vehicles has been calculated from the ratio of the average price car-days which amounts to HRK 906 and the number of daily 8 working hours. The average net price of one working hour of a truck amounts, thus, to HRK 113.25. The obtained price multiplied by time losses for trucks yields:

$183537 \mathrm{~h} \cdot 113.25 \mathrm{HRK} / \mathrm{h}=20785565.25 \mathrm{HRK}$.

Thus, during 2007 the minimal loss due to toll collection was estimated at an amount of $H R K$ 
$44,321,577.25$, which in countervalue amounts to US\$ 8,899,915.11 or EUR 6,096,503.06. Here, the time lost in queues has not been taken into consideration, nor the fuel waste nor indirect harmful impact on the environment [2].

\section{CONCLUSION}

Fast development and implementation of new methods of road toll collection motivated the study in which the bottom limit of losses was determined, which occur in the current toll collection system on the Croatian highways.

The time losses have been simulated exactly on the bases of the technical conditions set by the infrastructure and performances of passenger and heavy vehicles. Manipulative losses were measured in peak loads based on actual toll collection data. The results can be applied in arguing regarding the decision on the implementation of third-generation toll collection technology by means of GPS, because then there are no losses that are presented in the paper.

The losses due to queues, which also increase the environmental harmful impact have not been considered. Further research can go in this direction through the queuing theory during peak and off-peak periods.
Mr. sc. MILAN STANKOVIĆ

E-mail: milan.stankovic@hac.hr

Mr. sc. ZVONIMIR PILIH

E-mail: zvonimir.pilih@hac.hr

Hrvatske autoceste d.o.o.

Širolina 4, 10000 Zagreb, Republika Hrvatska

Mr. sc. BOŽIDAR IVANKOVIĆ

E-mail: ivankovb@fpz.hr

Sveučilište u Zagrebu, Fakultet prometnih znanosti

Vukelićeva 4, 10000 Zagreb, Republika Hrvatska

\section{SAŽETAK}

\section{IZRAČUN VREMENSKIH GUBITAKA NAPLATE CESTARINE}

Brzi razvoj tercijarnih djelatnosti ukida granicu radnog $i$ slobodnog vremena, radnih dana i godišnjeg odmora. Autoceste smanjuju vrijeme individualnog prometa osobnim i teretnim vozilima zbog veće putne brzine, no prilikom naplate cestarine dolazi do vremenskih gubitaka radi obaveznog zaustavljanja vozila. Cilj istraživanja prezentiranog u članku je egzaktan izračun gubitaka vremena kod takve naplate cestarine. Metoda simulacije na temelju tehničkih karakteristika vozila kombinirana je s analizom evidencije ritma naplate cestarine. Budući da u obzir nisu uzimani gubitci pri formiranju redova čekanja u vršnim i izvanvršnim opterećenjima, dobivene vrijednosti gubitaka najmanje su moguće. Daje se osvrt na različite tehnologije naplate cestarine.

\section{KLJUČNE RIJEČI}

putna brzina, ubrzanje, naplata cestarine, vrednovanje.

\section{LITERATURE}

[1] Cerovac, V.: Tehnika i sigurnost cestovnog prometa, Faculty of Transport and Traffic Sciences, Zagreb, 2002

[2] Gillen D., Jianling Li, Dahlgren, J., Chang, E.: Assessing the Benefits and Costs of Projects of Traffic Research Institute, California PATH research report UCB-ITS-PRR-99-9, Ožujak 1999. ISSN 1055-1425

[3] Feix, K.: Electronic toll system in the Czech Republic, ASECAP 2008 Days, Marrakesh, 20 of May 2008

[4] Pickford, A.: Pay time, Traffic technology international, Annual Review 2004 pp. 82-86.

[5] Schnacke, D.: A break with tradition, Tolltrans 2003. Pp. 36-40

[6] Del Pizzo, F.: Enhancing customer services: Telepas premium. Autostrade per l'Italia, ASECAP Marrakech, 2008 